\title{
Kyai And Character Education
}

\author{
${ }^{1}$ Abuddin Nata \\ ${ }^{1}$ Faculty of Tarbiyah and Teachers Training, State Islamic University (UIN) \\ Syarif Hidayatullah Jakarta, Indonesia \\ 1ªbuddin@uinjkt.ac.id
}

\section{ABSTRACT}

Kyai is recognized as one of Islamic Boarding School elements that has strategic role and function in character education. Through various excellence he has, a Kyai with an Islamic Boarding School he leads, not only can create an expert of Islamic Religion, but also a scientist, a public figure, even national leader and so on with noble character.

This paper used literature study and the results of field study and it had proven the statement above. The Kyai has big attention on character education. They do not only have concept, but also the method and authentic approach in character education. Beside that, through his superb mastery on literatures in Arabic, and supported by high commitments and responsibility, causes character education at Islamic Boarding School runs quite effective. Likewise through his high charisma, causes the role and function of Kyai in generating human with noble character seems un replaceable.

Keywords

Kyai, Islamic Boarding School, and Character Education

Article Received: 10 August 2020, Revised: 25 October 2020, Accepted: 18 November 2020

\section{Character Education}

In the Indonesian Dictionary, W.J.S. Poerwadarminta (1991: 445) defines character as tabi'at, character, mental characteristics, morals or character that distinguishes one person from another. Meanwhile, Michael Novak, as quoted by Thomas Lickona (2015: 81) said that the character is a compatible mix of all goodness identified by religious traditions, literary stories, wise men, and a collection of healthy people in history. In another sense, Ki Hadjar Dewantara (1962: 459484) equates character with etiquette or ethics, character and morality, that is the study of all matters of good (and bad) in human life that can constitute considerations and feelings, to concerning its purpose is action. Furthermore Prof. Suyanto, as quoted by Zubaedi, said: character is a way of thinking and behaving that is the characteristic of each individual to live and work together, both within the scope of family, community, nation, and country. Individuals with good character are individuals who can make decisions and are ready to take responsibility for the consequences of the actions that they do. Furthermore, Abdul Mujib and Dian Andayani (2013: 8-15) in addition to introducing the term character also introduces the terms moral, ethical, manners and morals. Character is interpreted as a person's character that is directly driven by the brain. Moral is a person's knowledge of good or bad while ethics is the science that investigates what is good and what is bad by paying attention to human deeds as far as the mind can know.

Meanwhile, among the followers of Islam, especially the Islamic Boarding School prefer the term moral, which is the science that teaches and distinguishes between good and bad based on the teachings of Allah and His Messenger. Imam alGhazali in Ihya 'Ulum al-Din volume III (p. 52) for example, defines morality as a state of nature that is firmly planted in a clean soul that radiates deeds easily without the need for thought and consideration. Supa'at (2014: 208) says that the essence of character is actually identical with morals; because the character is the values of universal human behavior, which includes all human activities, both in the context of relations with God, with himself, with fellow human beings, as well as the environment manifested in thoughts, attitudes, feelings, words, and actions based on norms religion, law, etiquette, culture and customs. Abuddin Nata in Sufism (2014: 4-5) mentions five characteristics of moral behavior, namely 1) actions that have been firmly instilled in the soul or ingrained; 2) actions that are easily carried out; 3) actions arising from the will of the 
person doing it; 4) the act that is done is actually, not pretended; and 5) deeds done sincerely because of God.

In Islam, moral teachings are very closely related to religion. This is further recognized by many scholars not only, but also by experts in general. Althaf al-Rahman bin Tsanaullah in al-Masail alAqadiyyah (2010: 1177-1179) said that religion helps humans in providing their needs for good examples and good examples, and comprehensive rules of life that bring goodness. Correspondingly, Thomas Lickona (2015: 64) said that religion for most people is a major reference that leads them to shape moral lives. Furthermore Supa'at (2014: 215) said, religion is as a guide and living system that is very instrumental for the formation of human character. Meanwhile Rachel M. McCleary \& Ribert J. Barro (2019: 8) said: religious beliefs are powerful incentives to behave according to the moral teachings of one's religion. This means: that faith in religion is a force that drives a person to behave in accordance with the moral teachings contained in a religion.

Thus human religion has a great opportunity to become human beings who have character, namely humans who have certain characteristics and identities that distinguish between one and the other. This attitude further underlies his activities in his life. A life based on good character will bring happiness. On the contrary, a life based on bad character will lead to disaster and misery. That is why character education becomes the main agenda of the Prophets and Apostles, spiritual figures, philosophers, poets, educators, preachers and so on. They put all their energy, time, and ability to realize the noble character. In this case the most pupular is the words of the Prophet Muhammad SAW which states: Bu'itstu utammima Makaarim al-akhlaaq: That I was sent by God on earth is to perfect noble character.

Before the Prophet Muhammad was born, there were already Hinduism, Buddhism, Confucianism and others. Huston Smith in Agama-Agama Manusia or Human Religions (1985: 42-70) for example, put forward Hindu teachings that remind about the path to God through Science, love, work, and psychological training. Furthermore, in Buddhism in Huston Smith (1985: 135) suggests eight kinds of truth, namely true knowledge, right will, right speech, right behavior, right livelihood, right effort, right mind, and right reflection. What is meant by what is true is something that contains the true meaning of truth, not faking, and is done in the right way. Likewise Kong $\mathrm{Fu}$ Tze or Confucius, as stated by Huston Smith (1985: 220), has a careful attention to personal and moral behavior.

By referring to the opinions above, character education is synonymous with moral, moral, ethical, ethical, ethical, ethical, polite, polite education. Doni Koesoema (2007: 134) said that character education is education that seeks to forge itself to be perfect so that the potential within him fully develops which then makes him more human. Ki Hadjar Dewantara (1962: 485) said that character education means supporting the development of children's lives, physically and mentally, from their nature to the direction of civilization in a general nature. David Elkin \& Freddy Sweet (2004) as quoted by Zubaidi (2011: 15) says that character education is the deliberate effort to help people understand, care about and act upon core ethical values, which means deliberate (conscious) efforts to help humans understand, care, and implement core ethical values. Suparlan (2019: 305) defines character education as a deliberate (conscious) effort to realize virtue, namely objectively good human qualities, which are not only good for individual individuals but also good for society as a whole. Character education is an effort to shape one's attitude, behavior, personality, character, and temperament in accordance with noble and noble values. Athiyah al-Abrasyi (1975: 22) states that character education is the soul of Islamic education.

Judging from the scope, character education is many kinds. Omar Mohammad al-Toumy alSyaibani (1979: 363) mentions the education of moral conscience, moral obligation, moral judgment, moral responsibility and moral rewards. While Thomas Lickona in Educating for Character (2015: 85-100) divides it into three parts, namely 1) Moral knowledge consisting of moral awareness, knowing moral values, determining perspective, moral thinking, decision making, personal knowledge ; 2) moral feelings 
consisting of conscience, self-esteem, empathy, loving good things, self-control, and humility; and 3) moral acts consisting of competencies, desires, and habits. Meanwhile, Ki Hadjar Dewantara (1962: 485-487) divided it into the character education stages of shari'ah, hakikat (essence), tarikat and ma'rifat. The shari'ah stage is done through habituation to children who have not been able to think abstractly; the nature of the stage is given through giving explanations to children who have begun to age, so that their moral actions do not taklid; the stage of the path is given to children who begin to mature by providing certain exercises that train mentally; and the ma'rifat stage is given to adults to have a broad understanding and in-depth awareness in carrying out moral actions.

However, among experts who conduct a study of character education, there is quite an interesting debate about whether a person's character can be formed or not. In other words whether a person's character is the result of the formation or indeed it has been there from the beginning. This debate is partly due to the existence of a number of internal or innate elements that have existed since human birth. Experts' studies, for example, refer to theories about human profiles or typologies based on the presence of a liquid element in the human body that influences their behavior. Differences in the structure of bile, lymph, glands and others that exist in a person, for example, is considered as an element that causes a difference in one's temperament or appearance. For example there are people who look cheerful, easy to get along, quiet, depressed, and so forth. In addition, the study of experts also found that genetic factors inherited from both parents also have an influence on a person's physical and non-physical behavior. Height, facial expressions, talents, hobbies, and even intelligence are much influenced by what exists in both parents.

Recognition of this fact causes everyone who will look for a mate, or match his sons and daughters often consider this genetic factor. In addition, the main teachings of Islam, the Qur'an and the hadith besides informing about the psychological potential that exists in humans, such as reason, conscience, instink, fithrah, ghadlab, and syahwat (lust), also informs about natural tendencies that are someone has. What is meant in this case is a positive tendency and a negative tendency (See Q.S.al-Shams, 91: 8). Some innate factors that a person possesses partly give rise to a psimistic and apathetic impression about the function of character education and conclude that character education is no longer needed. However, some others try to combine internal deterministic influences with external factors that are democratic. Imam al-Ghazali (1059-1111 AD), Ibn Miskawaih (d. $421 \mathrm{H} / 1030$ ) were those who included a collaborative view between internal and external factors and concluded that character education was still needed. They say if character education is not needed, then the sending of Prophets and Apostles becomes useless or meaningless. Ki Hadjar Dewantara (1962: 477 480) views that character education is used for perfecting or directing all the potential that exists in humans. Education has a role so that each person is able to highlight his good qualities and be able to suppress or control his bad qualities. $\mathrm{Ki}$ Hadjar Dewantara described an educator as a peasant. Corn plants will only grow into corn and papaya plants will only grow into papaya. Farmers cannot turn corn into papaya, or vice versa papaya into corn. The task of the farmer is to plant, care for, fertilize, water and maintain the plant so that it can flourish so as to produce dense fruit and so on. Furthermore Ki Hadjar Dewantara also acknowledged that humans have talents (qudrat) and free will (iradat) as gifts from God. But the talent and iradat must still be directed, so as not to collide with the free will possessed by others. Freedom possessed by someone is limited by freedom possessed by another person or society. In this connection, character education seeks to regulate human talent and free will so that it runs in harmony, peace, harmony, harmony and so on. This is where the values of character education, such as tatasamuh (tolerance), fair, democratic, tolerance, cooperation, helping each other and so forth are needed.

Thus, the efforts made by character education can be categorized as an act of control or improvement. Such self-control must be based on values not only from humans but also values from the Creator, God Almighty. These values are further complemented and elaborated with values derived from apostles, spiritual figures, 
philosophers, poets, scholars, experts, and so on. Because so many sources of value are involved in character education, there are values derived from Allah and His Rasul (religion), hereinafter known as akhlaq; value derived from reason, hereinafter referred to as ethics; values derived from conscience, hereinafter referred to as moral; values derived from traditions prevailing in society, hereinafter referred to as manners, courtesy, and manners. See Abdul Majid and Dian Andayani (2013: 8-15); Asmaran (1992: 6-9); Ki Hadjar Dewantara (1962: 459-484).

Studies by the author of a number of Islamic Boarding School in Java and outside Java in July to October 2019 show that character education is considered very important. Muhammad Hasan Rosyidi from the Head of Modern Islamic Boarding School Qismul Ri'ayah, Paciran Lamongan, East Java whom the author interviewed (Sunday, October 13, 2019) in this study, for example, cites the opinion of Imam Ahmad who said: Ta'allama al-adab qabla an ta'allama al-ilma: Study character before studying. Imam Ahmad's advice actually has long been practiced by the leading clerics. K.H.Khalil from Bangkalan Madura has long applied this concept. From stories, it was found that there was a santri who was not allowed to participate in the Koran but was only asked to clean the house, the yard, help the needs of the clerics and others. After all this time, the santri was told to go home but he did not want to because he still wanted to study. Finally, the students were shouted at by "thieves" which then forced them to go home. Finally the santri and his parents came to the kyai and asked for an explanation where Kyai K.H.Khalil replied, "that this santri has" stolen my knowledge ", and therefore he has enough knowledge, and is welcome home. In subsequent developments, it turned out that the students proved to be clerics. This can be explained by the role and function of noble morals as the foundation for becoming a cleric. The case of the santri mentioned above proves the theory's truth that to gain knowledge, a moral foundation is needed. So the nature of science in the world view of Islamic Boarding School comes from God and to get it must be done by first having a noble character. This is based on the word of Allah SWT, namely Kullun min indi rabbina wa maa yadzdzakkaru ila ulul al-baab, meaning: Everything is from the side of Our Lord, No one can take lessons except intelligent people. (Q.S. 3: 7).

Furthermore, conceptual character education is also found in the philosophy adopted by the Turus Pandeglang Islamic Boarding School in Banten. The concept of character education in this boarding school according to K.H. Tb. Dadang Idrus in an interview (Tuesday, August 13, 2019)) is based on learning to live life. According to him Islamic boarding school is as a place to learn to live a life that will be practiced in the community. In this Islamic boarding school, students are taught how to become a builder, install stone, brick, cut wood, and so on. This was taught by the kyai at Islamic Boarding School because it was this skill that was needed by the community at that time. These skills are always needed by the community and with these skills a santri already has stock of work that can sustain his life. When he becomes a cleric, he can practice his knowledge without having to rely on the mercy of his students. At one time there were guardians of students who did not understand the philosophy of the cleric which made the children or students at the Islamic Boarding School asked to go home, because the student's guardian was not in line with the treatment of the clerics. He wants his child to study the Koran and return to become a cleric, not a carpenter or a mason who builds a house. But once his parents intend to build his house in the village, then his child said: that "he was able to build the house, do not need to find another builder." Apparently the house can be built by his son well. Finally, the child's parents realized that what was taught by the kyai was very useful for his life. Finally his son was escorted back to the Islamic Boarding School to continue his education.

The concept of character education is also found at Jagat Arsyi International Islamic Boarding School, BSD Serpong Damai, Tangerang, Banten. The results of an interview with K.H.Budi Rahman Hakim, on July 29, 2019, in PP Jagat Arsyi it is known that character education carried out in this Islamic Boarding School is based on a worldview based on a humanist view. In this Islamic Boarding School every child is 
programmed according to the goals to be realized. A child, for example, wants to be a kyai or cleric, a businessman, a trader and so on, but all of these professions must be based on noble character.

From the description it can be seen that the Islamic Boarding School with its main actor, the kyai, is not only concerned with character education, but has a concept that is generally built from the viewpoints of the kyais. The teachings about noble character or noble character brought by the Prophets and Apostles, spiritual figures, philosophers, poets, and others are continued and taught by the kyai at the Islamic Boarding School. From this point of view, the kyai's view of character education is perennial style or what William F. O'nei (2008: 317) calls religious conservatism which believes that the faithful are not saved by their own efforts, but depend on God's will or choice. Perenialis views today's world situation as full of chaos, uncertainty, especially in moral, intellectual and sociocultural life. Perennialists offer a backward solution by reusing common values or principles that have become strong, strong outlooks on ancient and medieval times. However, this attitude has undergone a change, especially in the kyai in semi-modern and modern Islamic Boarding School.

\section{The Attraction of the Kyai}

Kyai is the most essential element of a Islamic Boarding School. W.J.S. Poerwadarminta (1991: 505) defines the Kyai as ulim ulama, occult teacher, district head (in South Kalimantan), or the designation of good luck (weapons, etc.). In the Islamic Encyclopedia Volume III (1999: 61) it is said that in Javanese society, the kyai is a person who is considered to have mastered Islamic religious knowledge and usually manages and manages a boarding school. Furthermore Mastuhu (1994: 126) defines the Kyai as caretakers of Islamic Boarding School who maintain religious values. Meanwhile Zamakhsyari Dhofier (2011: 93-100) in addition to expressing the meaning of the kyai as an honorary title for items considered sacred, or a title for the elderly in general, the kyai is also said to be a title given by the community to an Islamic expert who owns or becomes a leader of a Islamic Boarding School and teaches classic
Islamic books to his students. In West Java, kyai is sometimes called ajengan.

Viewed from their duties and functions, the kyai is an absolute source of power and authority in life in Islamic Boarding School. He is part of an elite group in the social, political and economic structure of Indonesian society. They have a strong influence on society, carrying out their duties as instructors and advocates of Islam, people who can always understand the majesty of God and the secrets of nature. Furthermore, the kyai who lead the big Islamic Boarding School have succeeded in expanding their influence until they are appointed as senior officials in the government, parliamentarians, ambassadors, and so on. They have also created a kind of kyai cadre regeneration pattern, among others through marriage, mutual assistance in establishing Islamic Boarding School by providing land capital and santri, and by building intellectual and kinship relations.

Of the various roles that can be assumed by the kyai, the main role of a kyai is as a teacher who teaches in Islamic Boarding School in the context of teaching student to become ulama. As a teacher, he should have the characteristics of a good teacher in general. Jamal Ma'mur Asmani (2016: 83-98) states that good teachers are teachers who master the subject matter in depth, broad minded, communicative, dialogic, combining theory and practice, gradually, having a variety of approaches, focus, democratic, humorous, but also remains serious. A good kyai is also a person who has a fatherly nature, and appears as the excellent parenting, that is loving his students and is responsible for his success in learning. Transmission and transfer of Islamic sciences; the maintenance of Islamic traditions, and the reproduction of ulama, which is the traditional function of Islamic Boarding School, as stated by Azyumardi Azra in the Introduction to the Book of Nurcholish Madjid about Bilik-bilik Islamic Boarding School or Islamic Boarding Schools (1997: xxi) can only be achieved and realized effectively if there are capable and strong-willed kyais. A good teacher who must be carried by the kyai is a kyai who has a superior ethos. Jansen Sinamo (2010: 4-183) mentions that there are eight ethos of good teachers, namely 
those who view teacher assignments as grace, trust, calling, self-actualization, worship, art, honor and service.

The attractiveness of the kyai in educating the students' morals is recognized by many as the most effective. This is partly due to some of the advantages of the kyai in general as follows.

\section{The Depth of His Religious Knowledge}

The nature of the ulema is actually similar to someone who holds the title of a professor. He has expertise in the field of religious knowledge which is recognized by the community of scholars. There are those who are experts in the field of hadith, such as K.H.Mahfudz al-Tirmai. Al-Tirmi's expertise in the field of hadith is not only recognized by Indonesian scholars, but by other scholars from various countries; and therefore when he was in Mecca, many scholars from the archipelago and other countries studied with him. Similarly, K.H.Hasyim Asy'ari or known as Hadratus Shaykh whose depth of religious knowledge is recognized by all scholars in Indonesia, including by K.H.Khalil from Bangkalan Madura who had been his teacher. However, besides mastering and proficient in his field, he also mastered other fields, such as Jurisprudence, theology and so on. This happened because during his studies at the Islamic Boarding School, he not only studied one field of religious knowledge, but he also studied other sciences. Furthermore, there are also Kyai who are experts in the field of fiqh, such as K.H.Bisri Syansuri. He is very expert in the field of Jurisprudence. There are also those who have expertise in the fields of al-Qur'an, Tajweed and Qira'at al-Sab'ah: How to Read the Qur'an with seven kinds of reading, as directed by K.H.M. Munawwir who founded the Krapyak Islamic Boarding School. There are also kyai who have expertise in the field of Sufism, interpretation, reckoning (astronomy), and so forth. Information about the depth and expertise of scholars in the field of religious knowledge can be found in their biographies.

The depth and expertise of the religious knowledge of the kyai occur because of the sincerity, perseverance, and tenacity in learning and the ability to self-teach in learning the science. K.H. Hasyim Asy'ari, for example, after he learned about religion and Arabic from his father, he continued to study with a number of scholars in various Islamic Boarding School. K.H.Hasyim Ash'ari, for example, studied grammar from Kyai Khalil Bangkalan Madura; and vice versa Kyai Khalil learned about the hadith to Kyai K.H.Hasyim Asy'ari. After completing studying religious knowledge from the kyai in the archipelago, the kyai studied religious knowledge to the world's major ulemas who used Mecca as a center of excellence. Such study activities are one of the things that strengthen people's recognition of the scholars' scientific expertise. Public interest in such kyai is actually an opportunity and conditions that are very conducive for the kyai to influence his admirers to have good morals.

\section{His Karomah and Barokah}

Karomah or barokah is a term that is found in the study of Sufism and tarekat in Islam, which is an extraordinary ability possessed by a kyai who is believed to be the result of his closeness to God obtained through a series of penances he lived. This ability is related to many things, such as curing diseases, the ability to prevent disasters, supernatural powers and so on. The results of Martin Van Bruinessen's research (1999: 280-281) as outlined in his book Kitab Kuning Islamic Boarding School an Tarekat or The Yellow Book of an Tarekat Islamic Boarding School for example, found a number of kyai who had karomah and barokah. He said many stories that have been (and continue to be) told about the Kyai's miraculous powers, his ability to see what hasn't happened, a fast career, or sudden wealth that comes to some who have gotten his blessing. K.H.Khalil from Bangkalan Madura, for example, is recognized as having high karomah and barokah. A santri who was not allowed to recite the Koran, but was only tasked with cleaning the house, providing various needs of the kyai and his family after many years, turned out to be a kyai after he returned to his hometown. This phenomenon is understood that through karomah and barokah kyai, someone who has rendered meritorious, solemn and obtains blessing from the kyai, and kyai prayer can be the reason for that person to become a kyai. This phenomenon is also 
understood as the need to first have a noble character, mental maturity that is strong enough, before someone draws and has knowledge. Knowledge without noble character and strong mentality will be dangerous. Similar to assets, thrones, and others that are not based on noble character and strong mentality can be misused.

The results of research conducted by the author around July to October 2019 on a number of Islamic Boarding School in and outside Java encountered a story about karomah and barokah owned by a kyai at a Islamic Boarding School. A person who now manages the As'ad Islamic Boarding School in Jambi, or the second generation of the kyai of the founder of the Islamic Boarding School, Tuan Guru K.H. Jamil Qadir in an interview (Monday, September 2, 2019) said that with his karomah and blessing, the kyai founder of this Islamic Boarding School, namely Mr. Guru (Teacher) K.H. Abdu Qadir Ibrahim bin K.H. Abdul Majid dared to oppose the Japanese colonial order by pounding the table which caused Japan to be silent a thousand languages and left with fear. In addition he also dared to face the Dutch military aggression in 1947 which was armed with modernism. When all the buildings in the city of Jambi caught fire, there were 10 kiosk buildings belonging to the kyai that were in the middle of the burning building, but did not catch fire. This phenomenon is understood as a form of karya karya.

With the power of karomah and blessing, the kyai can know a person's morals and mentality; and close to God, he asked for knowledge for someone he blessed. The kyai's authority in giving his blessing, karomah and barokah can actually be used optimally by the kyai to shape, improve and perfect one's morals. For the sake of wanting to get blessing, karomah and barokah from the kyai, one can certainly follow the commands of kindness given by the kyai.

\section{His Social Role}

As one of the characteristics of Islamic Boarding School is its social character. Although the initiator of the establishment of the Islamic boarding school was a kyai, the basic consideration used to establish the boarding school was the community's needs. Through the Islamic boarding school he built, the kyai wanted to change the community's situation for the better. Interviews (Friday, October 11, 2019) with a number of religious kyai at Tebuireng Islamic Boarding School and Denanyar Islamic Boarding School who were both in Jombang, found that the presence of Islamic Boarding School there was to eradicate $M$ Limo, namely maling (thieves), madon (men who like to whore), madat (the term for opium or opium that has been cooked and is ready to be smoked), mabok (drunk), maksiat (act immoral). Not only that, the social, economic, environmental and other conditions around the community are also getting better. This is due to the perseverance and seriousness of the kyai to change the attitudes and behavior of the community through education, preaching, role models and so on. In this way the community then shows their obedience to the kyai. Such conditions are actually an opportunity for the kyai to continue to provide guidance to the community in this way, the character of the community will be formed.

\section{The role of his heroism}

The presence of Islamic boarding schools in Indonesia does not only carry out religious orders related to inviting people to the path of God through da'wah and education, but to carry out religious orders related to social problems. To order others to do good (amar ma'ruf) and prevent them from doing evil (nahi munkar) is also a religious command. Implementation of this religious command will find its momentum when it is in the community. Islamic Boarding Schools in Indonesia always find various problems which at the same time open up momentum to carry out religious orders. Sociologically, Islamic boarding schools in Indonesia began to emerge at the end when the weakening of various Hindu and Buddhist kingdoms; and at the beginning of the Dutch colonialism. Because the factor of the period is too long, and the unpreparedness of the Hindu Buddhist kingdom to face the challenges of the times, which is caused by the weakening of mental attitude and internal solidity, causes Islam to have the opportunity to realize its vision, mission and purpose, namely to give rahmat or mercy to all nature by carrying out its mission of 
doing inner enlightenment, enlightenment of mind, and make changes for the better, by realizing the objectives of Islamic teachings by Imam al-Syathibi in al-Muwafaqot (1982: 125127 ) is to preserve the soul, preserve reason, preserve religion, preserve property, and raise offspring. Realizing the vision, mission and objectives of Islam is part of the struggle that is non-physical. Furthermore, because of the increasingly arrogant attitude of the Dutch, and the misery of the people in all aspects of life, the Islamic Boarding School took a non-cooperative attitude, opposed to Dutch policy and opposed them. The Dutch Colonial was seen as a pagan leader that could not be obeyed, various policies that had been very discriminatory and had made the people miserable had to be resisted. In this context history records a number of clerics who show their heroism in situations where military organization and defense and security are inadequate as a result of various limitations which then cause the kyai to take the initiative to appear as a hero. Because they are encouraged by a strong creed, sincerity and high ideals and the belief that death at the hands of God causes the kyai not afraid to face the pressure of the invaders. The results of experts' studies on Islamic Boarding School show that many kyai appear as heroes. In West Java, for example, the name K.H.Ahmad Sanusi from Sukabumi, K.H.Abdullah bin Noah from Cianjur; and K.H. By Iskandar from Bogor, they are listed as heroes. Likewise Hadratus Shaykh, K.H.Hasyim Asy'ari firmly issued a fatwa on the resolution of jihad in the face of the Dutch aggression II which began on November 10, 1947. The role of the kyai's defense and security was stated by Muhtarom HM in the Dynamics of Islamic Boarding School and Madrasah (2002: 40) as follows:

During Dutch colonization era, the influence of Islamic boarding school was very prominent in politics among the Javanese king and prince, trading and resident settlement. When the Dutch controlled the kingdoms in the archipelago, Islamic boarding school turn into the center of opposition and defense against Dutch. It can be concluded that Islamic boarding school as institution which has double function and can be seen from various dimensions including the pedagogical, religious and political dimensions.
The findings as the result that conducted by researcher on several Islamic boarding schools in July to October 2019 showed that almost all Islamic boarding schools which established in the pre-independence era were involved in the struggle for independence.

\section{Supernatural Power}

Supernatural power or physical and spiritual greatness of a person to defeat the opponent by unconventional and easy way, but in extraordinary and difficult way. For example, he can defeat many opponent in one movement from great distance, without detectable by anyone. In this way the opponent is overwhelmed, and in the end can be defeated easily and fast. This superiority is difficult for people, because it requires physical and mental requirements. For example, he should fasting for months, doing particular dzikir and wirid, as also having restrictions called tirakat. The reseacrh of Martin Van Bruinessen for example see the Kyai who believed and trusted by community for having supernatural power. Martin Van Bruinessen (1999: 279 ) for example says:

In Indonesia, the term wisdom refers to the Islamic magic; it was practiced by the Kyai, and not shaman. The Kyai of wisdom might also be contrasted as ideal type teacher. Kyai, the teacher who teach textual Islamic sciences, but also has some textual knowledge. In practice, many Kyai combine these two roles differently. The most well-known Banten Kyai of wisdom is Ki Armin (KH Muhammad Hasan Amin) from Cibuntu, near Pandeglang. He is the nephew of Kyai Asnawi Caringin. He was a tarekat teacher, who lead some of his visitors to be the followers of Qadiriyah tarekat.

Moreover, the number of Kyai and founders of Islamic boarding schools in Java, many who have this power. Mbah Muqoyyim, the nickname of KH Muqoyyim, founder and Kyai of the Cirebon Buntet Islamic Boarding School, for example, is descendant of Lebe Mangku, well-known as supernatural person, because he often did khalwat or isolate himself in the forest for a long time. M. Solahuddin in Napak Tilas Masyayikh (2017: 2829) said that Mbah Muqoyyim was the grandson of Prince Anom who was married to Anjasmoro, Lebe Mangku's child. Lebe Mangku had 
Anjasmoro as daughter who was married to Prince Anom. From this marriage, Anjasmoro had a child named Abdul Hadi, and Abdul Hadi later had several children, one of them is Mbah Muqoyyim. The relationship between kyai and supernatural power is also found in Tebuireng Islamic Boarding School, which the researcher studied in October 2019. M. Solahuddin in the Masyayikh Commemoration (2017: 125), said that according to Abdul Karim, as what M. Ishom Hadzik said that Kyai Hasyim is the descent of Bnarratorijaya VI, the last king of Majapahit Kingdom. The complete pedigree is Muhammad Hasyim bin Halimah bint Layyinah bint Mbah Shihab bin Abdul Jabar bin Ahmad bin Pangeran Sambo bin Pangeran Benowo bin Jaka Tingkir namely Mas Karebet namely Sultan Hadiwijaya bin Bnarratorijaya VI namely Lembu Peteng.

The superiority of kyai besides as supporting factor in carrying in complete the task at that time, also can be a role model for people. This situation is needed to form character.

\section{His personality}

In Indonesian Dictionary (1991: 768) personality means a man as individual (self human or people's own self); personality is the state of man as a person, the whole nature of person character (usually also shifted meaning; people who are good in nature and character).

Therefore, close personality means he has good behavior, character, temperament and character. A person with this personality is a good person. A Kyai is a good role model because his personality is known religious and avoid prohibition, also humble, sincere, like to help; firm in worship, having integrity and so on. Ustadz Abdul Halim, Head of the Education and Training Division of Tebuireng Islami boarding school in interview in October 2019 said that there were 5 values embedded here, such as sincerity, honesty, responsibility, hard work and tasamuh values. These values are actually the personality of $\mathrm{KH}$ Hasyim Asy'ari. The sincerity of $\mathrm{KH}$ Hasyim Asy'ari further told by Ustdaz Abdul Halim, that at one time, Kyai who were formerly KH Hasyim Asy'ari had studied with him, came to sit with KH.Hasyim Asy'ari about Hadith. However, even though they were studying with $\mathrm{KH}$ Hasyim Asy'ari at the time, $\mathrm{KH}$ Hasyim still assumed that they were his teachers who had no ex-teacher terms. When the teachers were resting, their dirty clothes were taken to be washed by KH Hasyim Asy'ari secretly. By doing this, KH Hasyim Asy'ari wanted to serve the teachers sincerely.

Another great personality is shown by $\mathrm{KH}$ Tubagus Muhammad Idris Sholeh as founder and Kyai of Islamic Boarding School in Turus, Pandeglang Banten. According to the narration of $\mathrm{KH}$ Dadang Idris as third generation of Kyai Turus, when the reseacher visited and interviewed him on August 13, 2019, it was said that $\mathrm{KH}$ Tubagus Idris Sholeh has a personality to succumb for winning. When he face his opponents, like the warrior who have denial many times, he still show affection in front of them; the warrior who are sick are often visited and assisted by him through difficulties, so that the warriors feel ashamed and converted to follow $\mathrm{KH}$ Tubagus Idris Sholeh. He also has the habituation of inviting his students to visit local residents, listen to the difficulties they face, and try to help them. The students were taught to have experience of real life in community. The students are prepared with the knowledge and skills needed by community. During Islamic boarding school, the students were not only taught about intellectual, but both contextual and practical . The students, for example, were taught to be builders, taught and trained on how to use river stones, lay bricks, shave wood, and even produce bricks. Parents of the students who do not have intellectualist perspective, feel insulting to what Kyai's treatment to their children. They moved their children from the boarding school to home. Yet it is not for a long time due to guilty feeling they have. Their children were returned to Islamic boarding school after they succeeded in building house by their own hands. Parents realize that the knowledge and skills taught by Kyai have succeeded to overcome family problems; and by having those skills, a child feels confident because it is beneficial economically. In addition, his religious knowledge will improve his charisma; he will be a sincere teacher, because he will teach his knowledge, without his students help financially. The main personality of the Kyai is very effective in supporting the character building of his 
students. His personality will place the Kyai as a great role model for his students. The power of the Prophet Muhammad to form morality influence his success to be role model.

\section{Financial}

The findings in the origin of Islamic boarding schools show varied circumstances. One of them, there is boarding school which its land given by the government or sultan, such as Sunan Ampel Islamic boarding school in Surabaya, Lirboyo Islamic boarding school, East Java, etc; there is an Islamic boarding school that originates from the endowment of a person handed over to Kyai, and he subsequently forms a wakaf management institution, and for its development the Kyai invites community participation, such as Gontor Ponorogo Modern Islamic Boarding School, and part of the Islamic Boarding School affiliated such as Darun Najah, Darul Muttaqien, and so on; and there are also Islamic boarding schools that were built from the kyai funds which were assisted by family members. Based on the findings conducted by researcher on Monday, July 29, 2019, for example it is known that the Jagat Arsyi International Islamic Boarding School, BSD Serpong, Tangerang Banten, for example, was built on land owned by KH Budi Rahman Hakim; Furthermore Bina Insan Mulia Islamic Boarding School in Cirebon was built on land owned by $\mathrm{KH}$ Ahmad Jazuli, Lc.MA.

Those condition of the Islamic boarding school has different effect for the rights and obligations of students. Students studying at first type of Islamic boarding school generally have no need to pay financially. They enter and stay in Islamic boarding school free. They cook, laundry, and manage their own lives. Various difficulties faced by the students such as lack of water, damage of cottage buildings, and so on are overcome together. The traditional Islamic boarding schools have shown the character of good life, namely a life that is based on a simple attitude, sincere, independent, qona'ah, patient, please help, and so on. This situation can form the character of Islamic boarding school graduates who are simple, sincere, independent, helpful, patient, and so on. The respect for Kyai is usually very high, due to the students rely and feel indebted to
Islamic boarding school . The relationship between students with first type of Islamic boarding school is usually very strong, because it is bound by a sense of brotherhood. They have eternal relationship.

On the other hand, the second type of Islamic boarding school (semi-modern) requires the existence of institutions, organizations, administration and management that govern it, so that bad management does not occur. The existence of Islamic boarding school must be their own burden and responsibilities. Therefore, operational funds are needed. The funding come from the wakaf management also come from student fee. This school require a base fee, school fee and other costs for students. However, the cost is affordable, because it is tied to the spirit of mutual help, as contained in the philosophy endowments. The respect to Kyai of this Islamic boarding school is not as strong as the respect given to the previous students. Basically, it is due to what the students obtained from Islamic boarding school comes from the students themselves, ie from tuition paid. Yet they know that the fee can not be compare with what the abilities they gain. The findings of researcher interview on Sunday, October 13, 2019 , with the principal of Muhammadiyah Modern Islamic Boarding School in Paciran, Lamongan, East Java, for example, show such conditions. This Islamic boarding school provides superior programs, in the the instruction using Arabic books, improving their reading and writing skills, and Arabic and English conversation, superior quality teaching of general sciences, such as various extra-curricular programs. They lived in dormitory, were provided with three meals a day, washed clothes, and had to pay for it. They must pay 5 million IDR per month for it, and tuition fees including food, shelter, laundry and other expenses only pay 500,000 IDR. The fee that paid by students is cheap if compared to the service they receive according to Drs. Muhammad Hasan Rasyidi, Head of Qismu Ria'ayah, Head of the Students Supervision Section, for example, adheres to the philosophy of the Islamic Boarding School that "superior education does not have to be expensive. "The view or assumption that superior Islamic boarding school has expensive fee is not including Muhammadiyah Modern Islamic Boarding School 
Paciran, Lamongan, East Java. Therefore, the distribution of superior education will be adequate.

Meanwhile, at modern Islamic boarding school, the respect given to Kyai is suspected to have less respect than the students of first and second type of Islamic Boarding School . The students of Modern Islamic Boarding School feel that what they receive here due to high tuition fee thay paid. Even the service they received may be considered to be still below compared with the costs that they paid. The findings of comparative study conducted by researcher on Monday, July 29 , 2019 on Jagat Arsy International Islamic Boarding School, for example, the fee to enter the Islamic Boarding School was 45 million IDR. While the monthly tuition fee, including three meals a day, washing clothes and others, is 5 million IDR.

Therefore, there is considerable influence among financial of Islamic Boarding School with respect to Kyai. Kyai that everything is based on sincerity, has a strong influence on shaping the character of the students. The role of Kyai in the form of sincerity to educate, creates attraction and admiration for students.

\section{Proximity to the Authority}

The sultan or the wise and good authority usually close to Kyai. Maulana Hasanuddin, Sultan of Cirebon, for example, is very close to Kyai. The closeness of the Sultan is based on the vision, mission and objectives of the da'wah, named to form humans to worship and stay away from their prohibitions, such as avoiding sexual act oot of marriage, drinking alcohol, gambling, and other misguided acts. The sultans felt happy if the vision, mission and objectives of the kyai's mission could be implemented. The wise and close authority to Kyai generally became the pattern of work and partnership of the Islamic empire. In all Islamic kingdoms, the relationship between Kyai and figures was very good. Moreover, they frequently entrusted with the task as Sultan advisor, held the position of headman, the consideration council, and preachers and educational needs of cmmunity. Closeness of the Kyai and authority, has a very big influence to place Kyai as important figure, has a strong influence and strong network. This situation is an opportunity for Kyai to influence the attitudes and views of community.

Through eight things that kyai has, such as the depth of knowledge, karomah, social roles, heroism, dignity, personality, economic ability, closeness to the authorities, and descendants of honorable people, the kyai can be highly respected by students. The respect is a condition where what is emulated, ordered and desirable kyai to his students can easily be implemented. This is the main task of kyai in fostering the students morality.

\section{Types of Character Values Taught in Islamic Boarding School}

The agreement of character education values that instilled into students soul as stated by Zubaedi in the Design of Character Education (2011: 7476), consists of 18 types. There are religious, honest, tolerance, discipline, hard work, creative, independent, democratic, curiosity, national spirit, nationalism, respect for achievement, friendly/communicative, love peace, care to environment, social care, and responsibility.

Based on findings at 16 Islamic Boarding Schools in Java and besides Java, it shows that all Islamic boarding schools teach character values based on the yellow book, the views of kyai, and vision and mission. In the Tebuireng and Denanyar Islamic Boarding Schools, Jombang, moral education adheres to moral teachings by Hadratus Shaykh KHHasyim Asy'ari as written in his book Adab al-Alim wa al-Muta'allim , a 110-page book published without knowing the year of publishing contained of eight chapters. In the first chapter it is stated about the virtues of knowledge, Kyai, learning and teaching, and the rights of Kyai who teach them. The second chapter discusses the ethical codes of student to Kyai that includes ten types of ethical, such as cleanse the heart from all the bad traits such as envy, bad behavior, evaluate the intention, young age to study; qona'ah in food, and clothing such as patience, dividing the day and night time carefully, less eat and drink, behave wara' $i$ and caution; less food that causes weakness, reduce sleeping, and not playing a lot. Next in the third chapter it discusses the ethics of student towards his teacher, which includes ten 
ethics, that is, having good morals, believe that his teacher mastered the knowledge he taught; prioritizing the needs of his teacher, looking at him with glorifying view; know their rights and do not forget them, be patient in serving them; do not enter the assembly except with their permission; do not sit in front of the teacher while eating; communicate in good words in front of his teacher; keep learning. The fourth chapter discusses the ethics of a student in learning. The fifth chapter of a teacher's ethics on student; Chapter six, teacher ethics in teaching; the eighth ethics of the teacher to his students, and eighth, the ethics to the books. The ethical content contained in the book of Adab al-Alim wa alMuta'allim is similar with Ta'lim Muta'allim written by Burhanuddin al-Zarnuji, and Tadzkirat al-Saami by Ibn Jama'ah.

Ta'lim Muta'allim book was studied by all Islamic boarding school students. At Jagat Arsyi Islamic boarding school in BSD Serpong Damai, Pesusren Turus Pandeglang Banten, Islamic boarding school Daar el-Qolam Gintung, and other Islamic boarding school, this book is studied. Martin Van Bruinessen (1999: 164-165) said, that this book is famous book that contains the attitude of obedience of students fully to their teachers. For many Kyai, this book is one of the main supporting pillars of Islamic boarding school education. In a discussion about the book by NU not yet intermittently, one participant suggested that this kind of book be banned because it would be taught because it would instill passive and uncritical attitudes. The reaction to this suggestion gives reason to believe that in the long run the work will remain part of the Islamic boarding school curriculum. This book is also available in some translations, in Javanese and Madurese. This 48-page book consists of 13 chapters that discuss the purpose and virtue of science and jurisprudence, intentions of study, choose fields of study, teachers, friends and associate with them, glorifying knowledge and experts, sincerity, motivation and hard work, competing competition, ability and order, resignation, the right time to learn, compassion and advice, the use of knowledge, the attitude of wara', the factors that cause strong and weak memorization, and about seeking fortune.
Moreover, the moral education material is taught through the Book of al-Akhlak li al-Banat and alAkhlak li al-Banin. The Book of Al-Akhlaq Lilbanin Lit Thulaab al-Madaris al-Islamiyah bi Indonesia has 4 volumes by Umar bin Ahmad Barja among the books that studied by all Islamic boarding school students. The teacher of Daar elQolam Islamic Boarding School in an interview (Monday, August 12, 2019) for example said that all students in junior and senior high schools were given moral lessons using Al-Akhlaq lilbanin book. Volume I, 31 pages, explains 33 problems briefly. After foreword, this book discusses the events of children, polite children, bad children, educating children start from early age, knowing Allah SWT, trustworthy children, obedient children, Prophet Muhammad SAW, ethics at home, Abdullah at his home, your loving mother, child ethics to her mother, righteous child and mother, caring father, child ethics to father, father's affection, child ethics to friends, two friends who love each other, child ethics to relatives, Mushthafa and relatives, Yahya, the ethics of the child to his assistant, the offended child, the ethics of the child to his neighbors, Hamid and his neighbors, when going to school, the ethics of people walking on the highway, the ethics of students at school, how student take care of school needs, how a student looks after school equipment, student ethics to his teacher, student ethics to his friends, general advice section 1, and general advice section 2 .

In addition, volume II, as thick as 48 pages contains 33 topics, after introduction part, next it has discussion of morality, child duty to Allah SWT, the beloved child, the obligation of the child to his prophet, part of the morality of the Prophet Muhammad (1), part of the morals of the Prophet Muhammad SAW (2), the affection of both parents, what are the obligations of the child to both parents, The story of Sayyidina Ismail AS, the story of Zainal Abidin Ra, the story of the slave who is always present, the story of the slave who is Jewish, the story of Hayut bin Syarih, the story of Zar bin Umar al-Hamdany, what is your duty to your brother, unity bequeathed strength, what is your duty to your relatives, Abu Talha alAnshary and his relatives, the story of young man and his female friend, what is your duty to your servant, this is the way of tolerance for your 
servant, Imam Ali al-Anshary and his relatives, the story of young man and his female friend, what is your duty to your servant, this is the way of tolerance towards your servant, Imam Ali alAnshary and his relatives ra and his maid, Qais bin 'Ashim and his slaves, what is your duty to your neighbor, The story of Ibn Umar ra and his maid, The story of is a man in his house with many rats, The story of, Imam Abi Hanifah, what are your obligations to your teacher, Imam Syafi ' $\mathrm{i}$ and his teacher, al-Rabi' bin Sulaiman and his teacher, al-Amin and al-Ma'mun and their two teachers, Ashmu'iy and Ibn Harun al-Rasyid, what are your obligations to your friends?

Furthermore, in Volume III, this book has 140 pages, contains 29 topics, such as after the introduction is revealed about shame and no shame, Ali as role model of shame in shame, 'Iffah and Qanaah and vice versa, testimony that gives advice, mandate and khiyanat, The story of is trustworthy children, Truth and Lie, The story of is honest and deceitful child, patient and haste, the effect of patience, gratitude and voracity, Ali as role model in patience, courtesy and anger, The story of of those who are merciful, compassionate and miserly, due to patience, gratitude and voracity, Ali as role model in patience, courtesy and anger, the story of of those who are merciful, compassionate and stingy, the effect of patience, gratitude and voracity, Ali as role model in patience, courtesy and anger, The story of is merciful, merciful and miserly, as a result of patience, gratitude and voracity, Ali in his patience, courtesy and anger, the story of of those who are merciful, compassionate and stingy, of the glory of the Prophet Muhammad SAW and his temple experts, tawadlu and patience, the story of of humble and arrogant people, sincere and show off, greatness of people who forgive, jealous and envy, punishment of people who are jealous, gossiping, testimony, divide and conquer, how people the complainant is destructive, closing: general advice (1), general advice (2).

Next, in IV book, this 72-page book contains 17 subjects. After introduction, this book discussed about traffic ethics, sitting ethics, speaking ethics, eating ethics alone, other eating ethics together, visiting ethics and asking for permission, visiting ethics of sick people, ethics of sick people, ethics of ziyarah ta'ziyah, ethics of friendship, the ethics of visiting glorified places, the ethics of friendship, the ethics of visiting noble places, the ethics of traveling, the ethics of dressing, the ethics of sleeping, the ethics of waking from sleep, the ethics of choosing and deliberating.

Therefore, based on 4 volumes of this book, the 112 topics presented in normative form with the proposition to quote verses of the Koran and alHadith start in volume II, with language that understood by children, interesting, concise and concise, and in the story starts from the Prophets, his Companions, especially Ali ibn Abi Talib, the famous caliph, figures, and interesting fictional stories. Ethics to all has been previously mentioned, such as ethics to God, the Prophet Muhammad, both parents, close friends, neighbors, ethics of eating, drinking, how to dress, etchic of sleeping, ethics of waking up, ethics at school, traveling, various kinds of morals that good, such as shame, truth, trust, forgiveness, humility, sincerity, patience, gratitude, and the opposite qualities that are bad and consequently, do pilgrimage, visit sick people, and so on. This book is complete and suitable for children.

Furthermore, the moral education is taught through the Book of Nashaih al-Ibad written by Syahibuddin Ahmad bin Hajar al-Asqalany who lived between $773 \mathrm{H}$ to $852 \mathrm{H}$. (79 years) and was instructed by Muhammad Nawawi bin Umar alJawiy, who lived at the end of the century $-19 \mathrm{M}$. This 80-page book contains 10 chapters including introduction. In the second chapter contains 30 advices, the third chapter, 55 admonitions, the fourth chapter, 37 admonitions, the fifth chapter 27 admonitions, the sixth chapter, 17 admonitions, the seventh chapter, 10 admonitions, the eighth chapter, 5 admonitions, the ninth chapter, the 5 chapters, and the tenth chapter, 29 admonitions. Therefore, this book contains 189 advices.

The advice was taken from the hadits of Prophet Muhammad. It is not including the introduction that besides quoting hadith, also quoting verses from the Koran that do not mention the name of the letter and the order of verse. Whereas the hadith before it was mentioned by the devotees was stated beforehand the sanad who gave a diploma to narrate the hadith. For example, the 
hadith is stated : al-raahimun yarhamuhumu alrahman tabaaraka wa ta'ala, irhamuu man fi alardli yarhamukum man fi al-sama ( Loving people will be loved by Allah Tabaraka wa Ta'ala, have mercy on earth, then the people in sky will love you too). Before the hadith was put forward it was stated that he had been graduated by al-'Allamah al-Sayyid Ahmad al-Mushthafa al-Musry after he was graduated by Sayyid 'Abd al-Wahhab bin Ahmad Farhat al-Syafi'i from his teacher who continued with Auliyah to Abdullah bin Umar bin al-Ash from the Prophet Muhammad. After that the hadith is explained words by words. For example, what is meant by those who love those on earth are children of Adam, and animals, do not kill, do good for them.

Moreover, in the following chapters, the advice is based on the hadith of Prophet Muhammad by stating the hadith was narrated from the Prophet Muhammad. In the second chapter, for example, the Hadith discusses two groups which are no better each other, named those who believe and benefit to other Moslems by speech, thought, influence, property, and body; connected with the hadith that says: whoever has woken up in the morning does not intend to hurt anyone, then his sins will be forgiven, and whoever has been intending to help the wrongdoers and fulfill all the needs of Muslims, then he will be equated with those who do pilgrimage by bearing the mabrur pilgrimage. It continued with a hadith which means that the servants who are most favored by Allah are the most beneficial to other moslems; and the most important charity is giving happiness to believer, such as relieving hunger or eliminating his distress, or meeting his worldly needs. It followed by the Hadith which states the two most hated classes, such as consider as an ally to Allah and troubling others by their bodies and property, and when all the commands of Allah Ta'ala are collected, they are returned to the two groups that are divided by Allah Ta'ala and love to His creatures. The explanation of this hadith is strengthened by the word of Allah SWT, without mentioning the name of the verse and its letter, which is the verse which means: Establish prayer and pay tithe, and the word of Allah SWT which means : You should thank me and to both your father and mother. (p. 4). However, the explanation of the hadith with the verses of the
Qur'an as contained in the second chapter is not obtained in subsequent chapters. In the following chapters, presented hadits only stated by the sanad and his narrators. For example it says: Saying the Prophet Muhammad whoever gives mercy to the believers, then Allah will write down the goodness for each believer. This hadith is mentioned by its narrators, named Imam Thabrani, and his sanad is Ubadah bin Shaamit. Yet there are also traditions that are delivered without mentioning the narrators and their sanad, for example the hadith that reads: there are ten cases that can prevent ten cases: i.e. the letter of al-Fatihah will prevent the wrath of Allah, the Letter of Yaa Sin will prevent thirst on the Day of Judgment; Dukhan's letter will prevent the hard work on the Day of Judgment; Surah Waqiah will prevent miserliness, Surah al-Muluk prevents the punishment of the grave Surah al-Kautsar prevents riots, Surah al-Kaafirun prevents disbelief when taken away, Surah al-Ikhlas prevents hypocrisy, Surah al-Falaq prevents malice of envious people, and Surat al-Naas prevents anxiety in the heart. (p. 79) The traditions that are in the form of sanad and narrator can be judged to be drastic, while the hadits without sanad and narrator are suspected to be weak.

In addition, the moral education is taught by the Book of Washaya (al-Aba li al-Ibna ) The full name of this book is Washaya al-Abaa li Abnaa aw al-Durus al-Awwaliyah fi al-Akhlaq alMardhiyah. As the name, it is illustrated that the book contains introduction of material to form morality which is pleaded by Allah. This book was written by Muhammad Syakir, an alIskandariyah scholar, Egypt. A small book that contains only its matan (no one has written it). It has 78 pages with twenty topics, including conclusion of advice. In introduction, the author of this book says that this book was prepared for those who study religious knowledge, the ethics needed by students to overcome problems. Twenty subjects divided into several themes. Firstly, the theme is related to morals towards Allah and His Messenger, advice about taqwa. Secondly, themes related to obligations towards both parents. Thirdly, themes related to obligations to friends. Fourthly, themes related to the teacher's advice to students, accompanied by 
themes about the ethics of a person who demands noble knowledge, ethics in muthalaaah, muzakarah and munadzarah, and ethics in a science assembly and in the muhadharah room. Fifthly, ethics has a variety of ethics of eating and drinking, worship ethics and entering the mosque. Fifthly, themes related to the virtues / benefits of shidiq (telling the truth), amanah (trustworthy), 'iffah (preserving lust), working and earning life by commander and zuhud. Sixthly, about muruah and self-esteem, repentance, khauf, raja, patient and gratitude, and sincere intention in working. Menawhile, the last advice contained suggestion to study Koran, memorize verses, and do not forget to understand its contents, and use tafseer or one of the Kyai who understand its meaning as reference. All advices were constructed based on the Koran and al-Sunnah. It can be concluded that those advices in line with the Koran verses, and quoting Koran verses related to the theme.

On the subject of teacher's advice to students include the role of teacher as parent who want their children to have healthy body, smart, clean hearted, educated mind, ethical, good in speech, appropriate in friendship, be loved by friends, helps the poor and lame, apologizing and forgiving, never stop shalat and does not ignore praying to Allah SWT. This statement looks like vision, mission, purpose and motto that have to be kept by the student. The advice about piety and obeying Allah, Rasul and parents in general is similar to some statements of ulama based on alQuran verses.

While the obligation or ethics that have to be done towards friends are to regard friends as family that should not be hurt and treated badly. When in education, it is better to provide space or a place that allows friends to sit in the forum, because if it is not, it will tighten the chest which can cause malicious attitude and have bad consequences. If a friend is sleeping on time, they should not be bothered with muthala'ah and mudzakara, and make your friends happy. If asked for help by a friend, you should not hesitate to help.

Furthermore, in the subject of ethics in studying, it is stated that study have to be earnest, full of motivation, no wasting time. It is recommended to get used to muthala'ah in earnest about the lesson before coming to the classroom; does not move from one discussion to another, before the previous topic has been well mastered. If the teacher asks students to sit in one place, they should not sit in different place, and if the seat is taken by a friend, then do not hold it and do not criticize, just tell the teacher, so the teacher can choose a certain seat. If the teacher has started reading the lesson, students should not talk or argue with fellow friends, do what the teacher instructs perfectly.

While in the matter of muthala'ah, mudzakarah and munadzarah, it is suggested to not to do it individually, but it is better to do it together with friends who can help to comprehend. If a lesson has been through and understood, it is better to check the book, or ask some friends who studied similar lesson.

Then. this book also advices to use the time for sports, so they can renew the spirit for studying after sports. If want to do sports, it is better to choose a place with fresh air, calm and conducive place, do not walk to fast, do not interfere others way, do not laugh, but smiling. If doing sports on the wide street, it can be done together in two lines, if the street is narrow it is better to do it in one line, and do not make traffic jam.

If in the forum or muhadlarah place, when passing through a group of people, greet them with the common lafadz, answering is wrong, do not answer the greet first to other greeter, asking permission in order to join the forum, because they might involved in a discusssion that should not be interfered by others, far of childish behavior (wanted to be served).

Next, wash hands if you want to eat, read basmalah, do not show greediness on food, but eat a good bite, because the stomach needs good food. Do not eat at the market, on the side of the road or in a hurry, because it will drive away muruah, and injure ethicists. Do not be stingy and bad, you should invite close friends to eat together, and if there is leftover food, it should be offered to those in need, and do not underestimate what people are giving, and if giving charity, they should not hurt the people. 
Next, they are advised to not to forget shalat, in order to really perform shalat that is obligatory together or berjama'ah. When shalat time is near, it is better to do wudhu, do not bother people in walking, save water, if it is the right time for shalat and mu'adzin is adzanm you should face on kiblat, sit calmly and appropriately, so shalat together or berjama'ah is khusyu' and tawadlu'.

For the students, they are suggested to be shidiq, amanah, 'iffah, which is qana'ah, do not want for food, drinks or anything that a friend had, do not obey self to raise apetite, drinks and some other short delicacy. They are recommended to keep muru'ah, which is dignity and self-respect.

The material of character education will be taught though The Book of Irsyad al-Ibad (Ila Sabil alRosyad. This Book was written by Syaikh Zainuddin bin Abdullah al-Azizy bin Zainuddin al-Malibary. In the beginning of the title, there is no reference about the origin of the book. However, in the introduction, it is said that this book was a book that has been developed (intakhabtuhu) of The Book of al-Zawajir wa Mursyid al-Thulab that had been written by Teacher and Kings of ulama, which was Syaikh Shihabuddin Ahmad bin Hajar al-Haitamy. This Book is called Irsyad al-'Ibad ilaa Sabil al-Rasyad with the hope on getting Allah SWT generosity in the form of sign and for all worshipers to join the eternal village (Dar al-Khulud), glorious and full of love. This purpose is based on hadith Bukhari and Moslem from Umar bin Khatatab ra, which said by meaning: I heard Rasulullah SAW spoke: That deed of charity depends on intentions, and deed for those who depends on the intentions. Whoever has the hijrah intention for Allah and Rasul of Allah, then those hijrah are for Allah and Rasul of Allah, and whoever has the hijrah intention for getting temporal matters or a woman that will be married, then the hijrah are back on the intention. (page. 2). The book of 120 pages is consisting five integrated knowledge, which are faith, education, fikih, moral and tasawuf, which divided in some few chapters and sections. There are 40 chapters, which are chapters concerning of faith, the virtue of science, wudhu, shower, shalat fardlu, shalat sunnah, jama'ah shalat, Friday shalat, something that is haram for men, visiting the sick, treating the sick, fasting, haji, the virtue of al-Qur'an, something that is said before and after sleeping, something that is said in some condition, zikir out of the set time, the virtue of shalawat to Nabi Muhammad SAW, a bit of syirik, takabur and feeling superior. All chapters that are contained in these chapters are divided into sections that most of them related to fikih, least of them related to faith, and by studying. Next, the chapter concerning of hate, gossiping (ghibah), bring to conflict, lying, good command and preventing the munkar, denounce desperate people, do some zalim, will, defying from badness, ungodly to parents, breaking silaturahmi, duel, jihad, seeking fortune, seeking fortune with birds, stars, magic and visiting shaman, adultery, drink khamar, false oath and lying saki. These all look like related to good moral that has to be followed; and bad moral that has to be kept away. Next is the chapter that discussed about atonement which consist of sections concerning the requirement for atone that can break the sin, and concerning al-khauf (scared of azab Allah) and alraja' (hoping for Allah SWT blessing).

Related to presentation pattern of each chapter and section in this book, it is started by referring to alQur'an verses that with its interpretation, and connecting to hadith with syarah, which is followed by explanation by citing statement of well-known ulama, such as al-Tajj al-Subki, alNawawiy al-Dimasyqi, and others. Every cited verse has no letter name and number. While each cited hadith said about sanad and narrator. When discussing about faith, it is started by citing verses that commanding human to have faith and takwa to the Lord. It is continued by citing hadith of Moslem Imam of Umar bin Khatab which has told about the coming of Jibril in the form of a man who wears clean white clothes and has black hair which has never known where it comes from. Then it touches its knees to Nabi Muhammad SAW kness then asks Nabi Muhammad SAW about faith, Islam, wisdom, Judgement Day, and the sign of his arrival. After answered by Nabi Muhammad SAW, the man agreed with him. Then Nabi Muhammad SAW asked to Umar bin Khattab about the person (in condition that Nabi Muhammad has already known). After Umar answer that Allah and Rasul of Allah who really know well about the person, Nabi Muhammad SAW explained that the man was Jibril the Angel. This hadith explains, in the book, by citing 
statement of well-known ulama and also strengthen the other hadits. (look page 2 and 3 ). Therefore, the study if each chapter and sections of this book is a strong-normative study which depends on comprehensive skills towards the verses and hadith based on hidayah from Allah SWT.

In the end of this book, it is revealed about the hadith which tells about the hadith of Ahmad and Thabrani from Mu'az bin Jabal which is the words of Nabi Muhammad SAW which means: If you all want, I will explain what Allah said to the Mukmin on the Judgement Day, what Allah said to them is that what Allah said on the Judgment Day to the Mukmim is do you want to meet Me. They answered: Yes, we want to. They say: O our Lord. Allah says: Say: We expect your apology and forgiveness, Allah says: I have given my apology and forgiveness. (p.117)

Furthermore, there are also Islamic Boarding Schools that teach morals through the Book of Risalah al-Mu'awanah. This book was written by al-Sayyid al-Syarif 'Abdullah bin 'Alwiy bin Muhammad Haddad al-Husainy, and had been published by al-Haramain Publisher; Singapore and Jeddah, without mentioning the year of writing and publishing. At the beginning (p. 2) of this book it is said, that the Risalah/Book was written due to the help and grace of Allah SWT which includes ways to follow the commands of Allah and His Messenger and encourage to like a promise that must be true that comes in order to give instructions and invitations to goodness and to spread knowledge, by citing the word of Allah which means: There should be among you all, a group that invites to goodness, directs to goodness and prevents to evil and that is the lucky ones, and the word of Allah which means: Invite people to the path of your Lord with wisdom, good advice, and the meaning of Allah word: Say this is my way, I invite you Allah to my mind and the people who follow me. These verses do not mention the names and serial numbers of the verses. Followed by citing the hadith which contains the command for people to live in the era of Rasulullah SAW, conveyed what he received from the Rasul to those who were absent, in the hope that they would understand, by being adhered to by hadith which means: Whoever who invites to the hidayah, for him the pahala as the pahala of those who follow it without reducing the slightest pahala, and whoever invites to heresy is sin as those who follow the sin without being reduced at all. (p. 2). After that, it is followed by a hadith which states that if an adam child dies, all his acts will be cut off except shadaqah jariyah, knowledge that is used and shalih children who pray for them. (p. 3) Continued with a hadith that says: that the kindest/generous person after me is someone who has knowledge and then spreads it, and on the Judgement Day will be resurrected as united people. In addition, it is also in line with the hadith which says, that all creatures will learn about the goodness of people who are knowledgeable, to animals in the ocean. However, the traditions are not mentioned about the sanad and narrators. (p. 3). After stating these hadits, it is sometimes followed by mentioning the verse of al-Qur'an without mentioning the letter and verse number, so between al-Qur'an and al-Hadis verses are mingled. In addition, this Book seems to emphasize the message or teachings contained in the hadith rather than mentioning the sanad and his narrators. (p.3).In the beginning (p.3-4) it is said that this book is named Risalah alMu'awanah wa al-Muwadhirah wa alMuwadzirah lir Raghibiina min al-Mu'minin fi Suluki Thariqat al-Akhirah). Means; Risalah that Help, Watch and Encourage those who have the Will on the Thariqah Afterlife). In the purpose of that it would be beneficial for Mukmim towards the Afterlife (p.4).

This Book only amounts to 40 pages. Even though there is no list of chapters and sections, there are sections in it, without mentioning the order. After reviewing and checking, this book contains 25 chapters. And each beginning of a chapter sometimes begins with words wa alaika (and obliged on you) (p. 4 and 5), which means it's mandatory for you all; sometimes with words wa yanbaghy (p. 9, which means and should be; sometimes with words wa 'I'lam, meaning you should know (p. 12). On pages 33-34 for example there is a phrase wa 'alaika bi al-aktsar min a'maali al-birri khushushan fi syahri Ramadhan fa inna tsawaabahu nafilah fiihi. This means that it is obligatory for you to raise your good deeds, especially in Ramadhan, because the pahala is an addition to you. Next is word 'alaika used for 
amar ma'ruf nahi munkar, doing justice to the people being led, atoning (p. 32), being patient (p. 23), being zuhud (p. 35), loving Allah (p. 37), keep close to Allah (p. 5). While the chapter that starts with the word wa yanbaghy which means to get in the habit of reading al-Qur'an, reading useful knowledge, (p. 9). While the chapter that starts with the word wa'lam (and know) among other things about Nabi habit of accelerating good action (p. 12). When compared between words wa 'alaika, with words wa yanbaghy (and it should be) and wa'lam (and know), it appears that the use of wa a'alaika is the most. This shows that what is discussed in the article is important, and the important ones are related to the issue of morals and tasawuf.

Then the material of moral is found in The Book of Tanqih al-Qaul written by al-'Alamah alSyaikh Muhammad bin Umar al-Nawawi alBantani, this Book was Syarah Lubab al-Hadis which had been written by al-Haafidz Jalal al-Din Abd al-Rahman Ibn Abi Bakrin al-Suyuthi. This Book has 64 pages with 40 chapters, about the virtues of science and ulama, the virtue of lafadz laa ilaaha illa Allah, the virtue of lafadz bismillahirrahmaanirrahiem, the virtue of shalat, the virtue of faith, the virtue of wudhu, the virtue of siwak, the virtue of adzan, the virtue of jama'ah shalat, the virtue of Friday shalat, the virtue of mosque, the virtue of ma'mum (al-'amaaim), the virtue of fasting, the virtue of fardlu, the virtue of sunan, the virtue of zakat, the virtue of shadaqah, the virtue of salam, the virtue of duha, the virtue of istighfar, the virtue of zikrullah the virtue of tasbih, the virtue of taubat, the virtue of faqir, the virtue of marriage, defying adultery, defying sodomy, preventing khamar drinking, the virtue of melempar, the virtue of good deeds to parents, the virtue of children education, the virtue of humble, the virtue of silence, the virtue of less apetite, sleep and rest, the virtue of less laugh, the virtue of visiting the sick, the virtue of remembering death, the virtue of qubur and its condition, preventing mourning the dead, the virtue of patience in disaster. Thus, this book is a mixture of virtues found in tauhid/faith, fikih, moral, tasawuf and children education. Related to fikih seem more dominant, followed by moral virtues such as avoidance to zina, sodomy, and drunk, followed by encouragement to do good to parents, educate children, be humble, quiet, reduce food, sleep and rest, not laugh much, visiting the sick, remembering death, do not mourn the dead, and be patient when exposed to calamities. While those related to tasawuf are istighfar, remembering Allah, glorifying, atoning and fakir. Furthermore, there is only one chapter that is related to faith, which is about the virtues of faith; and those related to education, are the virtues of science and ulama, and children education. Various subject matters in various fields of science are sometimes arranged systematically, for example mentioning fasting followed by zakat; and sometimes not systematic, for example after mentioning the virtue of shalat followed by discussing faith and wudlu. It is not clear the purpose of such an arrangement, it might take the model of al-Qur'an, which after mentioning the faith continued with learning, or doing research, or maybe for attractiveness, and other.

Model of presentation of material in The Book of Tanqih al-Qaul is also various. Sometimes it starts with mentioning a verse of al-Qur'an, hadith of Prophet, ulama statements, and other. When discussing the virtues of science and ulama, it starts with citing the relevant verse of al-Qur'an, however it is not mentioning the name and number of the verse order. That is a verse which means that Allah testifies that there really is no Allah but Him, the angels and the people of knowledge who Followed by inviting the reader to see how Allah SWT starts by calling himself, the angels and the experts of science, which shows that those who follow knowledge are in a noble and prime position. Followed by citing the hadith that comes from Ibn Mas'ud ra at the same time explaining sanad of this hadith, which said, " O Ibn Mas'ud, that to sit for one hour in the forum of science is not touching a pen, and not writing a single letter is considered better than freeing a thousand slaves, and seeing the face of a pious is better than a thousand horses being offered in the way of Allah, and your greetings to a pious person is better than one year of worship (p.7). But this hadith is not mentioned by the narrator. While in other parts, some hadits are mentioned by the narrator. Thus, this book opens opportunities to conduct research towards quality of hadits. But, it is strongly suspected that the level of those hadits are some sahih, mostly hasan, because between 
the deed and the rewards is not balance. Small deed such as say greetings to pious people, is considered as better than thousand years worship, seems the magnitude of the rewaard. Next when discussing the virtues of bismillah begins by quoting the hadith accompanied by mentioning its sanad which comes from Atha' and Jabir bin Abdullah, which says, Prophet said: when bismilillah lowered cloudy clouds ran eastward, the wind dwells, the wave stopped, animal bowed, demon are stoned, Allah swear with His majesty that nobody mentions His name for the sick but becomes medicines, and no one directs His name for something unless something causes barokah, for those who read bismillah will enter to heaven, as this is stated by His teachers, the Syaikh Tarekat, who are Syaikh Abd al-Qadir al-Jailaniy. (hal. 10). The sanad of those hadits are mentioned, but not the narrator. Next, in discussion in chapter of the virtues of prayer, it starts with citation of opinion from friend who said to Rasulullah SAW about ten rewards of kindness for people who read one shalawat. (page. 11). Furthermore, when discussing the virtues of faith begins by presenting the definition of faith according to language, which is to believe in the heart that is stored, knowing to justify it, whereas in religion, faith means to justify, which is knowledge of God and His attributes accompanied by obedience to all that is obligatory and sunnah, avoid prohibited and immoral acts, and it can be said that faith is al-din, al-syari'ah and al-millah, because religion is something that must be filled with obedience, avoid prohibited things. (hl.12). Next, when discussing about the virtue of children education, starts by quoting the hadits that comes from Anas ra who said, that Prophet said: that a child is mortgaged on the seventh day, given a name, shaved, and if it is up to six years starting to be educated, if up to nine years his bed is separated, and if until the age of thirteen years are required to pray, and if he is sixteen years married by his father, then raised his hand while saying: I have formed your moral, gave knowledge and get you married, I seek protection from Your slander and Your doom in hereafter. Thus, in Ihya 'Ulum alDin book (page. 49). Then it is followed by find out the hadists which mentioned its sanad and narrator, which is narrated by Turmudzi and alHakim from Umar bin Said al-Ash, which means that there is nothing more beautiful and more mainstream which are conducted by father to his child, rather than have good morals. (h. 49). Next, when discussing the virtues of reduce eating, sleeping, and resting, starts by quoting hadits which means: Prophet said: not an act that bequeaths a hard heart, ie likes to sleep a lot, likes to rest and likes to eat a lot. Followed with hadits which means: whoever is satisfied in the world will come on the Day of Judgment in hungry; and whoever is hungry in the world, then he will be satisfied in the afterlife. (p.52). This Hadith was not revealed by the Sanad and the narrator.

Then, moral materials are found in Minhaj al'Abidin Book. Minhaj al-'Abidin Book is written by Imam al-'Arif billah Ta'ala Zainuddin Hujjatul Islam Abi Hamid Muhammad bin Muhammad bin Muhammad al-Ghazali al-Thuusy (w.1111 M.). The volume of this Book is 108 pages, which contains of two parts. The title of the first part is Tha'at, which consists of 1 article about manners of wake up, 1 article of entering bathroom and 12 manners, which are manner of wudlu, manner of showering, manner of tayamum, manner of out from the mosque, manner goes to the mosque, manner after sunrise until it slips, manner of preparation for all prayers, manner of sleeping, manner of prayer, leadership and leadership, manner of jumuah prayer, manner of fasting. Part II discuss about avoiding prohibited acts, talk about immoral heart, and talk about manner of making friends and manner of communicating with al-Khaaliq, Allah Subhanahu wa Ta'ala and beings. The content of this book seems to have similarities to content of Ihya' 'Ulum al-Din, Nashaih al-Ibad and other books as mentioned above. In introduction part (page. 6), the writer of this book said that with taufiq of Allah that the result of this amounted 8 benefits. First, knowledge beneft, second taubat benefit, third, be friends benefit ('awaiq), fourth avoiding benefit, fifth mission benefit, sixth, heart cleanliness benefit (qawadih), seventh, benefit of praising and being grateful, and with the perfection of Minhaj al-Abidin book to Heaven. Now we follow those benefits by explanation of brief lafadz which includes the purposes intended in this situation in each of both in separated chapter. Insya Allah.

The pattern of presentation in this book starts by stating statements or relevant testimony which is 
next strengthen by paragraph of al-Qur'an without mentioning the name of letter and the number of paragraphs, then that paragraph is given opinion. In Uqbah al-Ula (The First Path), which is path in studying, al-Ghazali said: I say that with taufik of Allah, for those who look for sincerity and worship, first God should give you knowledge, because knowledge is a collection of pieces and there is a place back. Know that knowledge and worsip are two bright things, because both are exist in everything you see, everything you hear from creation of the creator and teaching of the teachers and advice of advisors, and thought of the thinkers, even because of that books are written and prophet are sent, even because of that sky and earth also everything inside it from all beings. Reflect two articles in Azza wa Jalla book, one of which is: The word of Jalla zikruhu: He is Allah who made seven levels of sky, and from earth like that every business is sent to make you all know that Allah SWT is The Almighty of everything, and that His knowing includes everything. And with this article is enough to be theorem, for the glory of knowledge, thus tauhid knowledge (page. 6). The second article, His Word Azza wa Jalla: I did not create Jinn and human unless to make them pray to Me (Q.S. al-Dzariyat, 51:56). This article is enough to be theorem of worship glory and keep conducting it. That explanation is next strengthen by hadits without mentioning its sanad and narrator. For example he said: That Prophet SAW said: That the parable of the pious perfection is compared to that of a slave, as is my preference for the lowest of my people; and his saying: That I look at a man of knowledge I prefer rather than one year worship accompanied by fasting and prayer; also connected with the hadith which means: Do you not want me to show you about a noble heaven expert. They answered: Yes Yaa Rasulullah. Prophet said that they are the ulama of my people (h.6). In the last part of this book, it is stated that people who are intelligent. The wroter of this book said: Then I said: in strange things from four things, is intelligent person but do not have knowledge, or he seek through knowledge between what is in both hands, whether he knows what happen after died by view of considering theorem, like and hearing in article, warning and shock. (page. 106).
By considering the elaboration above, there are several things as follows. First, that this Washaya book is very thick in character education both which is directly related to morals in studying, or other morals such as moral Allah, Apostle, both parents, friends, also other morals which generally applied in other activities, which is shidiq, amanah, iffah, taubah, khauf, raja, sabar, syukur, and maintain self-esteem. Second, that values of moral education in this book are similar to values of moral education in Ta'lim Muta'allim book. Those ethics which is mention are reason to why we must behave so. Some are based on theorem of al-Qur'an and al-Sunnah, and other are not accompanied by theorem of al-Qur'an and alSunnah, because the problem maybe has been considered as clear. Third, seen from its scope, content of morals, and focus which is discussed in this book is appropriate for students who are not only study in school, but also study in Islamic Boarding School, who are usually conduct shalat berjama'ah, attend the majors of science, conduct muhadharah, munadzarah, eat together, and exercise. Fourth, in terms of the values discussed in this book and the theorems used, it seems that this book has a normative, theological and intellectual style, because it is not accompanied by empirical examples of its practices that have been conducted by scholars in the past, as found in Ta'lim Muta'allim book. Fifth, values contained in this book seems close to tasawuf value which is teo centris. This seems based on theory, that science comes from Allah SWT, and this knowledge seems already written in al-Qur'an, Apostle, books which written by ulama, teachers, parents, and others just need to teach it, and the students can just read, understand, and memorize it. To get such knowledge, santri must have noble morals to Allah, Apostle, both parents, teachers, and friends. Sixth, that situation of learning which is illustrated in that book is learning situation which is empirical and teacher centris (teacher centered) which places the ulama, teachers, both parents, and friends as the only information sources. While students as people who need to receive information. Students are like empty glass that can be filled by water any time; or like white paper that can be written on anything; or like flexible candle on the table that can be shaped in anything; or like puppets that are moved by puppeteer. Teachers are very active in delivering, 
while students must be ready and active in receiving by preparing physic, senses, reason, conscience, mental, and so on. The ethics of teaching and learning in the era of information technology, openness, the availability of such wider teaching materials, the demands of democracy and high human rights, also the changing orientation of life, and very tight competition in life, it seems that the values contained in the book are still need to be refined.

In some Islamic Boarding School studied as mentioned above, some teaches abput books, and others not. In Islamic Boarding Schools which are categorized as pure salafiyah, which is Nur Sa'adah Islamic Boarding School, Cisauk, Cibungbulang Village, Bogor Regency, and alQur'an al-Mubarak Islamic Boarding School, in Cibeureum Village, Cibatok II, Cibungbulang District, Bogor Regecy West Java, and Turus Pandeglang Islamic Boarding School Banten, this book is taught. While in Daar el-Qolam Islamic Boarding School, Gintung, Balaraja, Tangerang, Banten, and Jagat Arsyi International Islamic Boarding School, this book is not taught.

\section{Closing}

Based on the elaboration above, it can be stated that position and role of kyai in character education in Islamic boarding school in Indonesia is very significant and strategic. Beside as founder, kyai also becomes the teacher, concept framers and creator of character education model in Islamic Boarding School. The understanding of kyai concerning morals includes the notions about character, morals, ethics, manners, behavior, manners and morals from the mind, conscience and good customs. This is in line with teaching guidance of al-Qur'an letter An-Nisa (4) paragraph 59, which is beside ask human to obey Allah (al-Qur'an) and obey al-hadis (Prophet Muhammad) also obey Ulil Amri (Ulama and Umara). Kyai is included in believer that human morals can be formed. They believe in Imam alGhazali in Ihya 'Ulum al-Din volume III (page 54) which states: If morals cannot be formed or cannot be changed, then the role of taushiyat, guidance and education become meaningless; meanwhile, Rasulullah SAW suggested to us to correct morals. The role of kyai in character education in Islamic Boarding School is supported by influence or its strong charisma which is formed from the depth of knowledge, characteristic, karomah, social role, heroism, economic ability, closeness to the rulers, and because of descendants of respected people.

Beside with skills in reading Arabic books, without punctuation or bald yellow books, kyai has taught character education values in Islamic boarding school through variative books, such as Akhlaq lil Banin, Ta'lim Muta'allim, Adab al'Alim wa al-Muta'allim, al-Washaya, Nashaih alIbad, Irsyad al-Ibad, and other books. Not only that, the kyai apparently not only looked at the importance of character education, but also had superior concepts and strategies in character education. However, the views, concepts and strategies in character education generally have not been written down in various scientific works.

\section{References}

\section{Books:}

[1] Al-Abrasyi, Muhammad Athiyah, alTarbiyah al-Islamiyah wa Fulasifatuha, (Mesir: Isa al-Baaby al-Halaby wa Syurakaauhu, 1395 H./1975 M.),

[2] Abd. Al-Baqi, Muhammad Fu'ad, alMu'jam al-Mufahras li Alfaadz al-Qur'an al-Karim, (Beirut: Dar al-Fikr, 1407 H./1987).

[3] Al-Ahwaniy, Ahmad Fu'ad, al-Tarbiyah fi al-Islam, (Meshir: Dar al-Ma'arif, tp.th.).

[4] Asmani, Jamal Ma'mur, Great Teacher Kiat Sukses Menjadi Guru Inspiratif, Inovatif dan Motivatif, (Yogyakarta:Diva Press, 20116), cet. I.

[5] Asmaran, Pengantar Studi Akhlak, (Jakarta: Rajawali Pers, 1992), cet. I.

[6] Asy'ari, K.H.Hasyim, Adab al-'Aalim wa al-Muta'allim,

(Tebuireng, Jombang:Maktabah al-Turats al-Islamiy, 1415 H.), cet. I.

[7] a-Bantaniy, Muhammad bin Umar alNawawiy, Tanqih al-Qaul, (SingapurJiddah, tp.th.).

[8] Baraja, Umar bin Ahmad, al-Akhlaq li alBanin lit Thulab al-Madaris al-Islamiyah 
bi Indonesia, (Surabaya:Ahmad Nabhan, 1385 H.)

[9] Bruinessen, Martin Van, Kitab Kuning Pesantren dan Tarekat: Tradisi-tradisi Islam di Indonesia, (Bandung:Mizan, 1999), cet. III.

[10] Dewantara. Ki Hadjar, Bagian Pertama Pendidikan, (Jogjakarta:Majelis Luhur Persatuan Taman Siswa, 1962).

[11] Dhofier, Zamakhsyari, Tradisi Pesantren Studi Pandangan Hidup Kyai dan Visinya Mengenai Masa Depan Indonesia, (Jakarta:LP3ES, 2011).

[12] Ensiklopedi Islam, 3 KAL-NAH, (Jakarta:PT Ichtiar Baru Van Hoeve, 1999),

[13] Al-Ghazali, Hujjatu al-Islam Abi Haamid, Imam, Ihya' 'Ulum al-Din, al-Juz III, (Beirut-Libanon: Dar al-Fikr, tp.th.)

[14] --------- Minhaj al-'Abidin, (Singapura:al-Haramain, tp.th.), cet. I.

[15] Al-Husainiy. Muhammad Haddad, Risalah al-Mu'awanah, (Singapura-Jiddah:alHaramain, tp. th.).

[16] Ismail, dkk., Dinamika Pesantren dan Madrasah, (Semarang:Kerjasama Fakultas Tarbiyah IAIN Walisongo Semarang dengan Pustaka Pelajar Yogyakarta, 2000), cet. I.

[17] Al-Jaawy, Muhammad Nawawiy bin Umar, Syarah Nashaih al-Ibad, (Surabaya, Indonesia:Kharisma, tp.t.).

[18] ---------, Muraqiy al-'Ubudiyyah, (Singapur: al-Haramain, tp.th.), cet. I.

[19] Kusumah, Indra, dan Vindhy Fitrianti, The Excellent Parenting Mendidikan Anak ala Rasulullah, (Yogyakarta:Qudi Media, 2012).

[20] Lickona, Thomas, Mendidik untuk Membentuk Karakter Bagaimana Sekolah Dapat Mengajar Sikap Hormat dan Tanggung Jawab (terj.) Juma Abdu Wamaungo, dari judul asli Educating for Character How Our School can Teach Respect and Responsibility, (Jakarta:Bumi Aksara, 2015), cet. IV.

[21] --------, Pendidikan Karakter Panduan Lengkap Mendidik Siswa Menjadi Pintar dan Baik, (terj.) Lita S, dari judul asli Educating for Character, (Bandung:Nusa Media, 2014), cet. II.
[22] ---------, Persoalan Karakter (terj.)Juma Abdu Wamaungo \& Jean Antunes Rudolf Zein, dari judul asli Character Matters, (Jakarta:Bumi Aksara, 2015), cet. III.

[23] Majid, Abdul dan Dian Andayani, Pendidikan Karakter Perspektif Islam, (Bandung: Remaja Rosdakarya, 2013), cet. III.

[24] Madjid, Nurcholish, Bilik-bilik Pesantren sebuah Potret Perjalanan, (Jakarta:Paramadina, 1997).

[25] McCleary, Rachel M., \& Robert J. Barro, The Wealth of Religions, (Princeton and Oxford:Princeton University Press, 2019).

[26] Mahmud, Ali Abdul Halim, Akhlak Mulia (terj.) Abdul Hayyie al-Kattani dari judul asli al-Tarbiyah al-Khuluqiyah, (Jakarta:Gema Insani, 2004.

[27] Al-Malibary, Syaikh Zain al-Din bin Abd al-Aziz bin Zain al-Din, Irsyaad al-ibad ila Sabil al-Rosyad, (Surabaya:Indonesia:Dar al-Ilmi, tp.t.)

[28] Mastuhu, Dinamika Sistem Pendidikan Pesantren, (Jakarta:INIS, 1994).

[29] Nata, Abuddin, Akhlak Tasawuf dan Karakter Mulia, (Jakarta:RajaGrafindo Persada, 20140, cet. XIII.

[30]----------, Studi Islam Komprehensif, (Jakarta:Prenada Media Group, 2018).

[31] O'neil, William F., Ideologi-ideologi Pendidikan, (terj.) Omi Intan Naomi, dari judul asli Educational Ideologies: Contemporary Expressions of Educational Philosophies, (Yogyakarta:Pustaka Pelajar, 2008), cet. II.

[32] Palmer, Joy A. (ed.) 50 Pemikir Pendidikan dari Piaget sampai Masa Sekarang (alih bahasa) Farida Assifa, dari judul asli Fifty Modern Thinkers on Education, from Piaget to the Present (Yogyakarta:Jendela, 2003), cet. I.

[33] Poerwadarminta, W.J.S. Kamus Umum Bahasa Indonesia, (Jakarta:Balai Pustaka, 1991), cet. XII.

[34] Sinamo, Jansen, 8 Etos Keguruan, (Jakarta:Darma Mahardika, 2010).

[35] Smith, Huston, Agama-agama Manusia (terj.) Saafroedin Bahar dari judul asli The Religion of Man, (Jakarta:Yayasan Obor, 1985). 
[36] Solahuddin, M., Napak Tilas Masyayikh Biografi 15 Pendiri Pesantren Tua di JawaMadura, (Kediri:Zam Zam, 2017), cet. VI.

[37] Al-Syaibany, Omar Mohammad alToumy, Falsafah Pendidikan Islam, (terj.) Hasan Langgulung, dari judiul asli Falsafah al-Tarbiyah al-Islamiyah, (Jakarta:Bulan Bintang, 1979).

[38] Tsanaullah, al-Syaikh Althaaf al-Rahman, al-Masail al-Aqidiyyah al-Muta'alliqah bi Adam AS, Juz III, (al-Madinah alMunawwarah:al-Jami;ah al-Islamiyah bi al-Madinah al-Munawwaroh, 1431 H./2010 M.), cet. I.

[39] Al-Thuusy, Muhammad al-Ghazaliy, Minhaj al-'Abidin, (Singapur-Jiddah:alHaramian, tp.th.)

[40] Zain al-Din, al-Syaikh Zain al-Din bin 'Abd al-'Aziz, Irsyad al-'Ibad Ila Sabil alRasyad, (Surabaya-Indonesia: Dar al-'Ilmi, tp.).

[41] Al-Zarnuji, Burhanuddin, Syarah Ta'lim al-Muta'allim, (Madinah:Al-Haramain, 1427 H./2009 M.)

[42] Zubaedi, Desain Pendidikan Karakter Konsepsi dan Aplikasinya dalam Lembaga Pendidikan, (Jakarta:Prenada Media Group, 2011), cet. I.

[43] Al-Zuhaili, Wahbah, Ensiklopedia Akhlak Muslim Berakhlak dalam Bermasyarakat, (terj.) Abdil Aziz, dari judul asli Akhlaq al-Muslim: 'Alaqatuha bi al-Mujtama', (Bandung:Noura Books (PT Mizan Publika, 2013),

\section{Journal}

[44] Abshori, Ahmad Afnan, "Konsep Pemikiran Harun Ar-Rasyid dalam Pendidikan Karakter," dalam Jurnal Penelitian, Vol.9, No. 2, Agustus, 2015.

[45] Fasa, Muhammad Iqbal, "Gontor AS The Learnung Contemporary Islamic Institution Transformation Toward The Modernity," dalam Jurnal Penelitian No. 14, No. 1, Juni 2017.

[46] Mustaqim, Siti Ma'rifah dan Muhammad, "Pesantren sebagai Habitus Peradaban Islam Indonesia," dalam Jurnal Penelitian, Vol.8, No.2, Agustus, 2015.
[47] Ritonga, Anas Habibi, dkk., "Manajemen Sumber Daya Manusia Berbasis Pendidikan Pondok Pesantren," dalam Jurnal Pendidikan, Vo..12, No.2, Agustus, 2018.

[48] Setiawati, Nanda Ayu, "Pendidikan Karakter sebagai Pilar Pembentukan Karakter Bangsa," dalam Prosiding Semnar Nasional Fakultas Ilmu Sosial Universitas Negeri Medan, Tahun 2017, Volume I, No. 1

[49] Supa'at, "Model Kebijakan Pendidikan Karakter di Madrasah," dalam Jurnal Pendidikan Islam, Volume III, Nomor 1 Juni 2014/1435 H.Jakarta, December 6th, 2019

[50] Prof. Dr.H.Abuddin Nata, MA.

[51] Drs.Ja'far Sanusi, MA.

\section{Curriculum Vitae of The Researcher}

[52] Abuddin Nata was born at Cibuntu Village, Ciampea District, Bogor Regency, West Java, on August 2nd, 1954. His father is M. Nata, a teacher of Qur'an and a poor farmer. His mother is Mrs. Siti Aminah, a housewife.

[53] His education started in 1961 until 1965 at Madrasah Diniyah, Jati Pinggir, Tanah Abang, West Jakarta. Then he continued to Compulsory Education Madrasah (MWB), Nagrog, Ciampea, Bogor in 1965-1968. Afterwards, he continued to Religion Teacher Education (PGA 4 Years) while studying at Nurul Ummh Islamic Boarding School, Nagrog, Ciampea, Bogor. His next education was Higher Religion Teacher Education (PGAA/PGA 6 years), while studying at Jauharatun Naqiyah Islamic Boarding School, at Cibeber Village, Cilegon District, Serang Regency, Banten until 1974. In 1978, the writer got Bachelor of Art (BA) degree, and in 1982 obtained Doctorandus (Drs) in the field of Islamic Religion Science from Faculty of Tarbiyah and Teacher Training State Islamic University of Syarif Hidayatullah Jakarta. Then in 1994, he obtained Magister of Art (MA), and in 1997 obtained Doctoral degree (DR/Ph.D) in the 
field of Islamic Religion with concetration was Islamic Education from Graduate Program of State Islamic University of Syarif Hidayatullah Jakarta. In 1999-2000, he followed Visiting Postdoctorate Program at Islamic Studies McGill University, Montreal, Canada.

[54] During his study at college, the writer was active in Islamic Students Association (HMI), Students' Commissariate, Students' Senate and The Board of Students' Activity Guidance (BPKM) State Islamic University of Syarif Hidayatullah Jakarta, League of Indonesian' Muslim Scholars (ICMI) Unit Organization (Orsat) Ciputat. Beside that, the writer also became the member of Local Research Council of DKI Jakarta, The Staff of Islamic Center Jakarta, The Speakers of ICMI South Tangerang City, and various other social organizations.

[55] In the field of work, the writer started to work as a teaching staff at Majelis Ta'lim al-Sa'adah Cipulir South Jakarta, lecturer of Islamic Education at Darul Ma'arif Institute Cipete, South Jakarta, Freelance Researcher at Development Studies Institution (LSP) Jakarta, non-permanent lecturer at University of Muhammadiyah Jakarta. Started from 1985, the writer became permanent lecturer at Faculty of Tarbiyah and Teacher Training State Islamic University of Syarif Hidayatullah Jakarta, and started from 2004, the writer becomes the lecturer of Graduate Program of University of Muhammadiyah Jakarta, Ibn Khaldun University (UIK) Bogor, University of Muhammadiyah Kendari, Sotheast Sulawesi, IAIN Raden Patah Palembang, South Sumatra, STAIN Pontianak, and various other universities.

[56] The positions that he ever handled were started in 1987, he became The Secretary of Practicum Office, The Chairperson of Islamic Education, Dean Assistant of General Administration Field at Faculty of Tarbiyah and Teacher Training UIN Syarif Hidayatullah Jakarta. Started from 19962004, he became the Rector's Assistant of General Administration Field UIN Syarif Hidayatullah Jakarta, and started from
2010 until now, the writer is The Dean of Faculty of Dirasat Islamiyah UIN Syarif Hidayatullah Jakarta.

[57] The experiences in other fields are such as becoming the preacher and khotib at various mosques in Jakarta and surrounding areas, speakers of religion events and dialogues about Islamic education at Mustang Radio, TVRI/AnTV, TP/MNC, and so on. During his time as a college student, he wrote at various mass media such as Pelita Newspaper, Republika Newspaper, Mimbar Ulama Magazine, Panji Masyarakat Magazine, and various other journals.

[58] Beside conducting research about Educational Quality at Schools (2011), The Model of Holistic Education, Humanistic, and Emancipatory 92013), and Islamic Religion Education at Schools (2013-2014), the writer also had produced paper work in the form of books such as; 1) The History of Religion, 2) The Science of Kalam, Philosophy, and Tasawuf, 3) AlQur'an and Hadits, 4) The Methodology of Islamic Studies, 5) Tasawuf Behavior, 6) The Interpretation of Educational Verses, 7) The Philosophy of Islamic Education, 8) The Thought of Islamic Education Figures, 9) The Innovative Figures of Islamic Education, 10) The History of Islamic Education, 11) The Pattern of StudentTeacher Relationship, 12) The Thought of Islamic Education and Western Education, 13) Masail al-Fiqhiyah, 14) Educational Management, 15) The Values of Spiritual Education in Islamic Tradition, 16) The Science of Islamic Education, 17) The Science of Islamic Education with Multidisciplinary Approach, 18) Islamic Education in Globalization Era, 19) The Paradigm of Islamic Education, 20) The Map of Islamic Thought Diversities in Indonesia, 21) The History of Growth and Development of Islamic Education Institution in Indonesia, 22) The Modernization of Thought of Islamic Education in Indonesia, 23) Heading to Successful Certification, 24) The Dimension of Spritual Education in Islamic Tradition; 25) Islamic Education in 
Classic Era and The Middle Era, 26) The Main Theme of Al-Qur'an, 27) Annotated Bibliography of Al-Qur'an, 28) The Challenge and The Opportunity of Islamic Education in Indonesia, 29) Capita Selecta of Islamic Education, 30) The Educational Concept by Ibn Sina, 31) The Islamic Perspective About Learning Strategies, 32) Building The Excellence of Islamic Education, 33) Education in Islamic Perspectives, 34) Education in Hadits' Perspective, 35) Medical Education in The Perspective of Al-Qur'an, 36) The Fiqh of Medics, 37) Behavioral Based Management Paradigm, 38) Comprehensive Islamic Studies, 39) The History of Islamic Education, 40) The Thought of Islamic and Western Education, 41) The History of Social Intellectual of Islamic Education, 42) The History of Education, 43) Capita Selecta of Islamic Education, 44) The Contemporer Issues of Islamic Education, 45) The Islamic Perspective About Medical Education, 46) The Innovation of Islamic Education in Indonesia, 47). Education in The Perspective of Al-Qur'an, 48) The Innovation of Education, 49) The Development of Teacher Profession, 50) Comprehensive Islamic Studies, 51) The Psychology of Islamic Education, 52) Islam and Knowledge, and 53) Islamic Education in The Global Era.

[59] The writer had visited some countries such as Saudi Arabia, Egypt, Turkey, Iran, USA, Canada, Australia, Japan, Philipine, Thailand, Hongkong, Singapore, Malaysia, Maroco, Netherland, France, Belgium, Switzerland, Italy, Rome, and Vatican.

[60] The writer has a wife named Elisah Angriani, a housewife and Commissioner of a company, with one son, Elta Diyarshay, bachelor of Physics Engineering, Bandung Institute of Technology (ITB) and now he is a Director of PT Elco, and Bunga Yustisia, Bachelor of Computer, Bina Nusantara University, now she is a housewife and an entrepreneur at once.
[61] The writer's address is at Akasia Street, Rt 002/012 Number 54 East Pamulang, South Tangerang, Banten. 